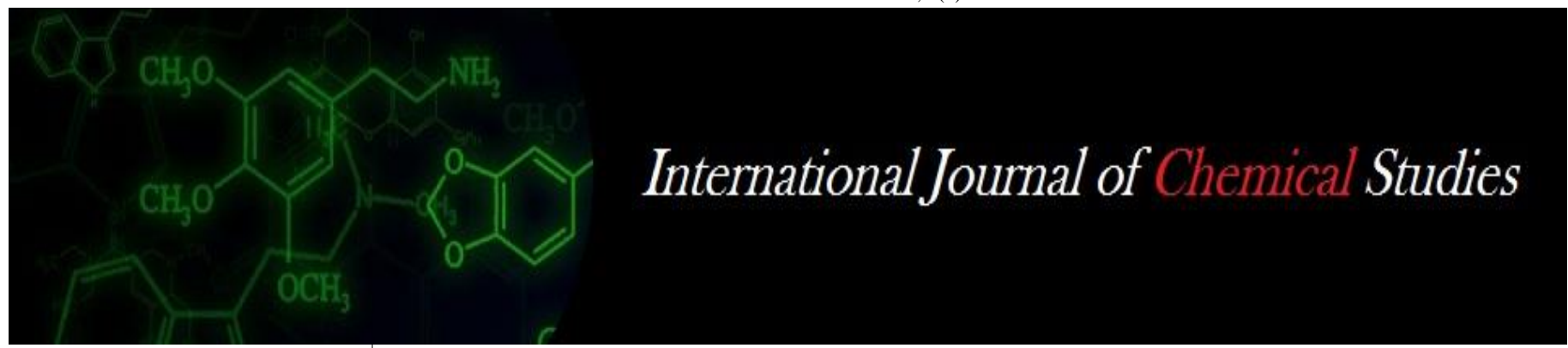

P-ISSN: 2349-8528

E-ISSN: 2321-4902

www.chemijournal.com

IJCS 2020; 8(4): 2265-2267

(C) 2020 IJCS

Received: 25-05-2020

Accepted: 27-06-2020

SP Sangeetha

Assistant Professor (Agronomy),

Department of Agronomy, Tamil

Nadu Agricultural University,

Coimbatore, Tamil Nadu, India

J Manohari

PG Research Scholar,

Department of Plant Pathology,

Tamil Nadu Agricultural

University, Coimbatore, Tamil

Nadu, India
Corresponding Author: SP Sangeetha

Assistant Professor (Agronomy), Department of Agronomy, Tamil

Nadu Agricultural University,

Coimbatore, Tamil Nadu, India

\section{Growth and yield improvement of blackgram (Vigna mungo (L.) through foliar application of nutrients in southern zone of Tamil Nadu}

\author{
SP Sangeetha and J Manohari
}

DOI: $\underline{\text { https://doi.org/10.22271/chemi.2020.v8.i4y.9967 }}$

\begin{abstract}
A field experiment was conducted to study the effect of foliar nutrients on growth, yield and quality of blackgram (Vigna mungo (L.) Hepper under rainfed condition during summer season 2018 at the research farm of Agricultural College and Research Institute, Kudumiyanmalai, Pudukkottai district, Tamil Nadu. The experiment was laid out in Randomized Block Design with three replications having eight treatments namely $\mathrm{T}_{1}$ : Control (No foliar spray), T2: Foliar spraying of DAP @ 2\%, T3: Foliar spraying of NAA 40 ppm and $100 \mathrm{ppm}$ Salicylic acid, T4: Foliar spraying of Panchagavya @ 3\%, T5: Foliar spraying of Agniasthra @ 3\%, T6: Foliar spraying of PPFM @ 1\%, T7: Foliar spraying of TNAU Pulse wonder @ 5 $\mathrm{kg} \mathrm{ha}^{-1}, \mathrm{~T}_{8}$ : Foliar spraying of sea weed extract @ 1\%. Growth and yield attributes were significantly influenced with different treatments and recorded higher value with the foliar spray of TNAU Pulse wonder @ $5 \mathrm{~kg} \mathrm{ha}^{-1}$ at flowering and 15 days later. Maximum grain yield $\left(898 \mathrm{~kg} \mathrm{ha}^{-1}\right.$ ), net return ( ₹ $30,648 \mathrm{ha}^{-1}$ ), higher grain protein and carbohydrate content was obtained with the application of TNAU Pulse wonder@ $5 \mathrm{~kg} \mathrm{ha}^{-1}$, which was at par with treatment of foliar spray of DAP @ 2\%.
\end{abstract}

Keywords: Black gram, foliar spray, TNAU pulse wonder, DAP

\section{Introduction}

Pulses are wonderful gift of nature with unique ability of biological nitrogen fixation, deep root system, mobilization of insoluble soil nutrients and bringing qualitative changes in soil properties which make them known as soil fertility restores. India is the largest producer and consumer of pulses in the world, accounting for 33 per cent of world area and 22 per cent of world production of pulses. The area under pulses in India is around 25.28 million hectare with a production of 18.84 million tonnes and productivity of $745 \mathrm{~kg} \mathrm{ha}^{-1}$ (Agrl stat, 2018) ${ }^{[1]}$. Blackgram [Vigna mungo L.] is one of the most important pulse crop of rainfed areas grown throughout the country. This crop is grown in different cropping system as a mixed crop, catch crop, sequential crop in the country. Blackgram seed contains $25-26 \%$ proteins, $60 \%$ carbohydrates, $1.5 \%$ fat and minerals combination, amino acid, and essential vitamins etc. It is used as nutritive fodder especially for milch cattle. It is also used as a green manuring crop. The per capita consumption of pulses in India is around $30-35 \mathrm{~g}$ as against the recommendation of Indian Council of Medical Research (ICMR) at $45 \mathrm{~g}$ and World Health Organization (WHO) at $80 \mathrm{~g}$ per day. The requirement of pulses for billion people as per ICMR recommendation would be 17.15 million tonnes, where as WHO's recommendations for well nourishment the requirement must be 29.2 million tonnes (Kannaiyan, 2000) ${ }^{[6]}$. Grain legumes constitute an important part of human diet in many parts of the world. In Tamil Nadu, the total area under black gram is 4.06 lakh ha with a production 3.01 lakh tonnes during 201718 (GOI, 2018) ${ }^{[5]}$. The current level of production is well below the requirement, and future projected demand for 2022 also mounting high to 16.1 million tonnes respectively to meet the specified per capita requirement (Praduman Kumar et al., 2009) ${ }^{[10]}$. Potential of blackgram is very low because the fact that the crop is mainly grown in rainfed condition with poor management practices and also due to various physiological, biochemical as well as inherent factors associated with the crop. Apart from the genetic makeup, the physiological factor viz., insufficient portioning of assimilates, poor pod setting due to the flower abscission and lack of nutrients during critical stage of crop growth, coupled with a number of disease and pest 
constitute the major constraints for the poor yield (Mahala et al., 2001) ${ }^{[7]}$. The poor production potential of pulses is attributed to poor photosynthate of pods and seed setting, which may be improved through foliar application of macro and micronutrients and growth regulators. The nutrients when added in small amount by exogenous foliar application modify the natural growth regulatory system right from seed germination to senescence in several pulses. Moreover, foliar feeding practice would be more useful in early maturing crops, which could be combined with regular plant protection programmes. Besides, foliar application is credited with the advantage of quick and efficient utilization of nutrients, elimination of losses through leaching and fixation and regulating the uptake of nutrient by plants (Manonmani and Srimathi, 2009) ${ }^{[8]}$. It has been well established that the fertilizer elements which are absorbed through roots can also be absorbed with equal efficiency through foliage. Application of nutrients through foliar spray at appropriate stages of growth becomes important for their utilization and better performance of the crop (Anandhakrishnaveni et al., $2004)^{[2]}$. Foliar application of nutrient and growth regulator at pre flowering and flowering stage was seen on reduction in flower drop percentage in blackgram (Ganapathy et al., 2008) ${ }^{[4]}$. Hence keeping the above in view the present investigation was under taken to evaluate the effect of foliar nutrition on growth, yield and quality of Blackgram.

\section{Materials and Methods}

A field experiment was conducted to study the effect of foliar nutrients on growth, yield and quality of blackgram (Vigna mungo (L.) Hepper during summer season 2018 at the research farm of Agricultural College and Research Institute, Kudumiyanmalai, Pudukkottai district is situated in the southern zone of Tamil Nadu state at $10^{\circ} 38^{\prime} \mathrm{N}$ latitude and $78^{\circ} 82^{\prime} \mathrm{E}$ longitude at a altitude of $99 \mathrm{~m}$ above mean sea level and receives fairly well distributed mean annual rainfall of $960 \mathrm{~mm}$. The maximum and minimum temperature ranged from $42.38^{\circ} \mathrm{C}$ to $28.14^{\circ} \mathrm{C}$ was observed during the cropping period. The experimental site has a typical chromustert soil (Order: Vertisol). Composite soil samples from 0-30 $\mathrm{cm}$ depth were collected from the site before laying out the experiment and analyzed for various physical and chemical properties. The textural class of soil was red sandy loam with organic carbon of $0.51 \%$, low in available nitrogen $\left(154 \mathrm{~kg} \mathrm{ha}^{-1}\right)$, medium in phosphorus $\left(12.6 \mathrm{~kg} \mathrm{ha}^{-1}\right)$ and potassium $(172 \mathrm{~kg}$ $\left.\mathrm{ha}^{-1}\right)$. The soil $\mathrm{pH}$ is 5.9 and electrical conductivity is $12.9 \mathrm{dS}$ $\mathrm{m}^{-1}$. The experiment was laid out in Randomized Block Design with three replications having eight treatments namely $\mathrm{T}_{1}$ : Control (No foliar spray), $\mathrm{T}_{2}$ : Foliar spray of DAP @ 2\%, $\mathrm{T}_{3}$ : Foliar spray of NAA $40 \mathrm{ppm}+100 \mathrm{ppm}$ Salicylic acid, $\mathrm{T}_{4}$ : Foliar spray of Panchagavya @ 3\%, T5: Foliar spray of Agniasthra@3\%, T6: Foliar spray of PPFM @ 1\%, T7 : Foliar spray of TNAU Pulse wonder @ $5 \mathrm{~kg} \mathrm{ha}^{-1}, \mathrm{~T}_{8}$ : Foliar spray of sea weed extract @ 1\%. The blackgram variety TNAU Blackgram (VBN) 6 was used for experiment. Foliar application was given once at 30 DAS and second at 45 DAS to all the treatments except $\mathrm{T}_{1}$. The spacing adopted was $30 \mathrm{x}$ $10 \mathrm{~cm}$. The data on growth parameters, yield attributes and yield were recorded. The quality parameters viz., grain protein and carbohydrate content was analysed.

\section{Result and Discussion}

\subsection{Effect of foliar spray on growth characters}

The growth characters of blackgram viz., plant height, leaf area index (LAI), number of branches, and total dry matter production were influenced significantly by foliar application of nutrients (Table 1). Foliar spray of TNAU pulse wonder @ $5 \mathrm{~kg} / \mathrm{ha}\left(\mathrm{T}_{7}\right)$ at flowering and 15 days later recorded significantly higher growth components viz., plant height $(34.3$ and $41.5 \mathrm{~cm})$, number of branches plant ${ }^{-1}(2.8$ and 6.1$)$ at 45 DAS and harvest respectively and leaf area index (3.28) at flowering, which was on par with DAP 2\% foliar spray $\left(\mathrm{T}_{2}\right)$. At harvest, $\mathrm{T}_{7}$ (TNAU pulse wonder @ $5 \mathrm{~kg} / \mathrm{ha}$ ) recorded significantly higher total dry matter production (DMP) (3984 kg ha-1) over rest of the treatments which was on par with $\mathrm{T}_{2}$ (DAP 2\% spray) (3856 kg ha-1). The productivity of blackgram is low due to poor management practices and various physiological and biochemical stress associated with the crop. Apart from the physiological factors viz., insufficient partitioning of assimilates, poor pod setting due to flower abscission and lack of supply of nutrient during critical stage of the crop. One of the easier ways is foliar application of nutrients for nutrient availability and supplementing the nutrient requirement to increase the productivity. The increase in growth components with the application of TNAU pulse wonder $\left(\mathrm{T}_{7}\right)$ and DAP $\left(\mathrm{T}_{2}\right)$ might be due to beneficial effect of foliar application of nutrients at flowering and pod development stage might have easily absorbed and better translocated in the plant and maintained constant requirement of $\mathrm{N}$ and $\mathrm{P}$ at the reproductive stage of the crop. Presence of growth regulators in pulse magic, which are known to influence a wide array of physiological parameters like alteration of plant architecture, assimilate partitioning, promotion of photosynthesis, uptake of nutrients (mineral ions), enhancing nitrogen metabolism, promotion of flowering, uniform pod formation, increased mobilization of assimilates to defined sinks, improved seed quality, induction of synchrony in flowering and delayed senescence of leaves (Sharma et al., 2013) ${ }^{[11] .}$

\subsection{Effect of foliar spray on yield attributes and yield}

The yield attributes (number of pods plant ${ }^{-1}$ and number of seeds $\operatorname{pod}^{-1}$ ), grain and haulm yields of blackgram was markedly increased due to the foliar application of nutrients (Table 2). Application of TNAU pulse wonder @ $5 \mathrm{~kg} / \mathrm{ha}\left(\mathrm{T}_{7}\right)$ recorded significantly higher number of pods plant ${ }^{-1}$ (31.5), number of seeds pod $^{-1}(7.7)$, grain yield $\left(898 \mathrm{~kg} \mathrm{ha}^{-1}\right)$ and haulm yield $\left(1444 \mathrm{~kg} \mathrm{ha}^{-1}\right)$ over rest of the treatments and which was on par with $\mathrm{T}_{2}$ (DAP $2 \%$ ). Increasing in the grain yield of blackgram with foliar spray of micro and macronutrients and growth regulators might be the reason for variation in the yield components like number of pods/plant, number of seeds/pod and test weight, which had direct influence on the grain yield. Reproductive efficiency of pulse like number of flowers formed, flower drop and fruit drop percentage were significantly influenced by various foliar spray treatments. The predominant effect of foliar application of nutrients and growth regulator at flowering and pod formation stage was seen on reduction in flower shed and increasing fruit set percentage (Ganapathy et al., 2008) ${ }^{[4]}$.

\subsection{Effect of foliar spray on quality}

Application of TNAU pulse wonder @ $5 \mathrm{~kg} / \mathrm{ha}\left(\mathrm{T}_{7}\right)$ registered significantly higher grain protein content $(24.8 \%)$ and carbohydrate content $(58.7 \%)$ over rest of the treatments, and it was on par with $\mathrm{T}_{3}$ and $\mathrm{T}_{2}$ (24.6 and $24.5 \%$ respectively). The increase in protein content may be due to higher availability of nitrogen throughout the growth period due to application of fertilizer at basal dose and also supply of foliar nutrients and growth regulators at critical periods of crop 
growth (flowering and pod development stage). The similar findings were also reported by Dixit and Elamathi (2007) ${ }^{[3]}$ and Mondal et al. (2011) ${ }^{[9]}$.

Table 1: Effect of foliar nutrition on growth characters of blackgram

\begin{tabular}{|c|c|c|c|c|c|c|}
\hline \multirow[b]{2}{*}{ Treatments } & \multicolumn{2}{|c|}{ Plant height $(\mathbf{c m})$} & \multicolumn{2}{|c|}{ Number of branches plant $^{-1}$} & \multirow{2}{*}{$\begin{array}{c}\text { Leaf Area } \\
\text { Index } \\
\text { at flowering }\end{array}$} & \multirow{2}{*}{$\begin{array}{c}\text { DMP } \\
\left(\mathrm{kg} \mathrm{ha}^{-1}\right) \\
\text { at harvest }\end{array}$} \\
\hline & 45 DAS & at harvest & 45 DAS & $\begin{array}{c}\text { at } \\
\text { harvest }\end{array}$ & & \\
\hline $\mathrm{T}_{1}:$ Control & 29.6 & 32.4 & 1.6 & 4.8 & 2.28 & 2886 \\
\hline $\mathrm{T}_{2}$ : DAP @ 2\% & 34.0 & 40.5 & 2.8 & 6.0 & 3.23 & 3856 \\
\hline $\mathrm{T}_{3}$ : NAA $40 \mathrm{ppm}$ and $100 \mathrm{ppm}$ Salicylic acid & 33.8 & 37.8 & 2.7 & 5.9 & 2.74 & 3535 \\
\hline $\mathrm{T}_{4}:$ Panchagavya @ 3\% & 33.4 & 37.1 & 2.6 & 5.8 & 2.55 & 3288 \\
\hline $\mathrm{T}_{5}$ : Agniasthra@ $@ 3 \%$ & 29.4 & 34.2 & 2.2 & 5.4 & 2.44 & 3050 \\
\hline $\mathrm{T}_{6}:$ PPFM @ $1 \%$ & 31.6 & 36.2 & 2.4 & 5.6 & 3.17 & 3487 \\
\hline $\mathrm{T}_{7}$ : TNAU Pulsewonder @ $5 \mathrm{~kg} / \mathrm{ha}$ & 34.3 & 41.5 & 2.8 & 6.1 & 3.28 & 3984 \\
\hline $\mathrm{T}_{8}:$ Sea weed extract @ 1\% & 30.5 & 35.9 & 2.3 & 5.3 & 2.47 & 3126 \\
\hline SEd & 0.56 & 0.75 & 0.07 & 0.14 & 0.07 & 97.4 \\
\hline $\mathrm{CD}(\mathrm{p}=0.05)$ & 1.8 & 2.5 & 0.16 & 0.29 & 0.16 & 196.6 \\
\hline
\end{tabular}

Table 2: Effect of foliar nutrition on yield attributes, yield and quality of blackgram

\begin{tabular}{|c|c|c|c|c|c|c|}
\hline Treatments & $\begin{array}{c}\text { No. of pods } \\
\text { plant }^{-1}\end{array}$ & $\begin{array}{c}\text { No. of } \\
\text { seeds pod }^{-1}\end{array}$ & $\begin{array}{c}\text { Grain yield } \\
\left(\mathbf{k g ~ h a}^{-1}\right)\end{array}$ & $\begin{array}{c}\text { Haulm yield } \\
\left(\mathbf{k g ~ h a}^{-1}\right)\end{array}$ & $\begin{array}{c}\text { Grain protein } \\
(\mathbf{\%})\end{array}$ & $\begin{array}{c}\text { Carbohydrate } \\
(\%)\end{array}$ \\
\hline $\mathrm{T}_{1}:$ Control & 19.6 & 6.80 & 612 & 1097 & 22.3 & 55.4 \\
\hline $\mathrm{T}_{2}$ : DAP @ 2\% & 30.0 & 7.63 & 875 & 1402 & 24.5 & 58.4 \\
\hline $\mathrm{T}_{3}:$ NAA 40 ppm and 100 ppm Salicylic acid & 28.6 & 7.28 & 851 & 1315 & 24.6 & 58.0 \\
\hline $\mathrm{T}_{4}:$ Panchagavya @ 3\% & 26.5 & 7.12 & 828 & 1254 & 23.4 & 57.3 \\
\hline $\mathrm{T}_{5}:$ Agniasthra @ 3\% & 25.2 & 7.02 & 815 & 1245 & 22.6 & 57.9 \\
\hline $\mathrm{T}_{6}$ : PPFM @ 1\% & 27.2 & 7.21 & 831 & 1356 & 23.5 & 57.6 \\
\hline $\mathrm{T}_{7}:$ TNAU Pulse wonder @ 5 kg/ha & 31.5 & 7.70 & 898 & 1444 & 24.8 & 58.7 \\
\hline $\mathrm{T}_{8}:$ Sea weed extract @ 1\% & 24.5 & 7.05 & 825 & 1289 & 22.8 & 57.7 \\
\hline SEd & 0.78 & 0.18 & 21.9 & 31.8 & 0.60 & 1.42 \\
\hline CD (p=0.05) & 1.62 & 0.38 & 42.27 & 65.5 & 1.23 & 2.94 \\
\hline
\end{tabular}

\section{Conclusion}

The results of the present investigation indicated that, the reproductive efficiency of blackgram like the number of flowers formed, flower drop and fruit setting percentage were significantly influenced by various foliar spray treatments. However, application of TNAU pulse wonder @ $5 \mathrm{~kg} / \mathrm{ha}$ significantly increased the plant growth, total number of branches, higher dry matter production compared to control and resulted in significant increase in number of pods formed, percentage of fruits set and grain yield. The foliar spray of DAP 2\% spray showed similar results as that of TNAU pulse wonder@ $5 \mathrm{~kg} / \mathrm{ha}$.

\section{References}

1. Agricultural Statistics at a Glance. Government of India Ministry of Agriculture and Farmers Welfare Department of Agriculture, Cooperation and Farmers Welfare Directorate of Economics and Statistics. 2018: 68

2. Anandha Krishnaveni S, Palchamy A, Mahendran S. Effect of foliar spray of nutrients on growth and yield of green gram (Phaseolus radiatus). Legume Res. 2004; 27(2):149-150

3. Dixi P, Elamathi S. Effect of foliar application of DAP, micro nutrients and NAA on growth and yield of greengram (Vigna radiata L.). Biology. 2007.

4. Ganapathy M, Baradhan G, Ramesh N. Effect of foliar nutrition on reproductive efficiency and grain yield of rice fallow pulses. Legume Res. 2008; 31(2):142-144.

5. GOI. Pulses revolution from food to nutritional security. Crops Division. Govt of India, Ministry of Agriculture and farmers welfare, Department of Agriculture, Cooperation and farmers welfare, Krishi Bhavan, New Delhi, 2018.
6. Kannaiyan K. Biofertilisers - Key factors in organic farming. The Hindu Survey of Indian Agriculture, 2000. 165-173.

7. Mahala CPS, Dadheech RC, Kulhari RK. Effect of plant growth regulators on growth and yield of blackgram (Vigna mungo) at varying levels of phosphorus. Crop Res. 2001; 18(1):163-165.

8. Manonmani V, Srimathi P. Influence of mother crop nutrition on seed and quality of blackgram. Madras Agric. J. 2009; 96(16):125-128.

9. Mondal M, Rahman MA, Akter MB, Fakir MSA. Effect of foliar application of nitrogen and micronutrients on growth and yieldin mungbean. Legume Res. 2011; 34(3):166-171.

10. Praduman Kumar PK, Joshi, Pratap S, Birthal. Demand projections for food grains in India. Agricultural Economics Research Review. 2009; 22:237-243.

11. Sharma P, Sardana V, Sukhvinder Singh K. Dry matter partitioning and source-sink relationship as influenced by foliar sprays in groundnut. The Bioscan. 2013; 8:11711176. 